компетентностей учителя математики на основі дослідницького підходу у навчанні 3 використанням інформаційних технологій : автореф. дис. на здобуття наук. ступеня д-ра пед. наук : 13.00.02 «Теорія та методика навчання (математика)»/ Сергій Анатолійович Раков; НПУ ім. М. П. Драгоманова. - Х., 2005. - 44 с. 8. Семенець С. П. Методика навчання математики (підготовлено на основі концепції розвивальної освіти) : [навч. посібник] / С. П. Семенець. - Житомир : Вид-во ЖДУ ім. І. Франка, 2009. - 536 с. 9. Скафа Е. Средства формирования методической компетентности будущего учителя в системе эвристического обучения математике / Е. Скафа // Mathematics and Informatics /journal of educationresearch. - Vol. 56. - Number 3. $\quad$ Sofia, 2013. - C. 211-223. 10. Скворцова С. О. Динамічна модель формування методичних компетенцій у майбутніх учителів / С. О. Скворцова // Педагогіка формування творчої особистості у вищій і загальноосвітній школах: зб. наук. пр. / редкол. : Т. І. Сущенко (голов. ред.) та ін. - Запоріжжя, 2011. - Вип. 17 (70). - С. 177-183. 11. Стефанова Н. Л. Теоретические основы развития системы методической подготовки учителя математики в педагогическом вузе : дисс. ... д-ра пед. наук : 13.00 .02 «Теория и методика обучения и воспитания (математика)» / Наталия Леонидовна Стефанова. СПб., 1996. - 366 с. 12. Тарасенкова Н. А. До проблеми формування методичних компетентностей майбутнього вчителя математики профільної школи / Н. А. Тарасенкова, I. А. Акуленко // Розвиток педагогічних наук в Україні і Польщі на початку XX століття : зб. наук. пр. - Черкаси, 2011. - С. 273-279. 13. Чайковский Ю. В. Диатропика, эволюция и систематика: к юбилею Мейена : сб. ст. с приложением полного списка трудов С. В. Мейена, составленного И. А. Игнатьевым / Ю. В. Чайковский. - М. : Тов-во науч. изд. КМК, 2010. - 407 с.

УДК 796.01

Вадим Андріанов, Тарас Андріанов

\title{
ПРОФЕСІЙНО-ПЕДАГОГІЧНА ПІДГОТОВКА МАЙБУТНЬОГО ВЧИТЕЛЯ ПОЧАТКОВИХ КЛАСІВ 3 ФІЗИЧНОЇ КУЛЬТУРИ
}

Андріанов В. С., Андріанов Т. В. Професійно-педагогічна підготовка майбутнього вчителя початкових класів 3 фізичної культури.

У статті розглянуто питання формування професійно-прикладної фізичної підготовки майбутнього вчителя освітянської галузі, проаналізовано сутність професійно-прикладної фізичної підготовки та розглянуто її структуру в ситуаціях професійної діяльності особистості.

Ключові слова: професійно-прикладна фізична підготовка, структура, особистість, професійна діяльність.

Андрианов В. Е., Андрианов Т. В. Профессионально-педагогическая подготовка будущего учителя начальных классов по физической культуре.

В статье рассмотрен вопрос формирования профессионально-прикладной физической подготовки будущего учителя в сфере образования, проанализирована сущность профессионально-прикладной физической подготовки и рассмотрена его структура в ситуациях профессиональной деятельности личности.

Ключевые слова: профессионально-прикладная физическая подготовка, структура, личность, профессиональная деятельность. 
Andrianov V. E., Andrianov T. V. Professional and pedagogical training of the future teachers of primary classes on physical culture.

The article considers the question of formation of professional-applied physical training of the future teachers of educational sphere, analyzed the essence of professionalapplied physical training and considered its structure in situations of professional activity of the person.

Key words: professional-applied physical preparation, structure, personality, professional activity.

Професійно-педагогічна діяльність у сучасних умовах характеризується високою динамічністю, пов'язаною з виникненням нових спеціальностей, розпадом звичної системи і правил навчання, зміною стереотипів побудови професійної кар'єри і професійного розвитку. Важливу роль відіграє визначник престижності тієї чи тієї спеціалізації. Тому система вищої освіти повинна бути провідним чинником у професійній системі підготовки фахівців, здатних успішно й ефективно реалізувати себе в умовах, що змінюються, аналізувати професійні ситуації, приймати професійні рішення, використовувати свій потенціал у професійному й особистому житті в інтересах суспільства і держави.

Останнім часом проблема розвитку професійно-прикладної фізичної підготовки студентської молоді стає об'єктом досліджень багатьох науковців. Значущість окресленої проблеми підкреслюється у працях М. Віленського, О. Дрозд, І. Ільїнича, Т. Круцевич, Б. Куленіна, Ж. Ломака, О. Максименко, Р. Сафіна, Д. Платонова, В. Попенченко, О. Ярмощука та ін.

Перебудова освіти відповідно до світових стандартів та здобутків цивілізації передбачає розроблення нової гуманітарної парадигми, пошуки перспективних моделей, систем і технологій професійно-педагогічної підготовки учителя [4, с. 40]. Система фізичного виховання вимагає від майбутніх вчителів фізичної культури початкових класів спеціальних знань медико-біологічного, психолого-педагогічного, програмно-нормативного циклів, що сприяє ефективності педагогічної діяльності.

Низький рівень теоретичних знань із професійно-прикладної фізичної підготовки пояснюється низкою недоліків у навчальній програмі 3 фізичного виховання. Вагомою причиною, яка впливає на ефективність вивчення та засвоєння теоретичного розділу з фізичного виховання та професійно-прикладної фізичної підготовки зокрема $\epsilon$, як зазначає М. Божик, неправильна структуризація навчального матеріалу за кредитами й низька інформативність студентів, відсутність науково-методичної та спеціальної літератури 3 професійно-прикладної фізичної підготовки [2, с. 50].

Виявляючи й обгрунтовуючи сукупність педагогічних умов, спрямованих на підвищення ефективності процесу формування в майбутніх учителів фізичної культури розвитку здатності орієнтації у професійних цінностях майбутнього вчителя фізичної культури та оволодіння студентом досвіду рефлексії професійнопедагогічної діяльності, показали, що актуальною на майбутнє є робота за такими напрямами: індивідуалізація і диференціація процесу формування суб'єктної позиції майбутнього вчителя фізичної культури; розгортання цього процесу в комплексі «ВН3 - система підвищення кваліфікації- школа» 3 відповідним розробленням теоретико-методологічних, методичних і дидактичних аспектів [6, с. 175].

У процесі розвитку потенційних можливостей сучасного фахівця, становлення його професійних умінь i навичок важливого значення набуває професійноприкладна фізична підготовка (ППФП), що забезпечує готовність фахівців до 
самовдосконалення та високопродуктивної трудової діяльності у галузі фізичної культури і спорту.

Усебічний розвиток особистості, тобто розвиток фізичних і духовних сил, творчих здібностей і дарувань є найважливішим завданням вищої школи. Перед вищими навчальними закладами постає важливе завдання залучення студентів до систематичних занять фізичними вправами, підвищення працездатності, покращення підготовки їх до професійної діяльності, формування рухових навичок і стійких звичок до занять фізичною культурою, виховання в них колективізму, патріотизму, цілеспрямованості до спортивно-масових та фізкультурно-оздоровчих заходів.

Змістовий аналіз ППФП (iї функціонального, ціннісного, діяльнісного аспектів) свідчить про те, що вона має великі потенційні можливості у формуванні всебічно розвиненої особистості. Однак у реальній фізкультурній практиці ці багаті можливості використовуються неповною мірою. 3 огляду на це стає актуальним питання вдосконалення професійно-прикладної фізичної підготовки майбутніх учителів як ефективного засобу покращення рівня їх фізичної підготовленості, здоров'я, інтересу до занять фізичними вправами та професійної компетенції, тобто спрямованість на певну педагогічну діяльність.

Mema cmammi полягає у висвітленні педагогічних умов, що сприяють формуванню професійних умінь і навичок майбутніх учителів у процесі ППФП, прагнення їх до саморозвитку та самореалізації у процесі фізичного виховання.

Завдання роботи: визначити умови формування професійних умінь і навичок особистості майбутнього вчителя та розкрити наявність ціннісних орієнтацій до оволодіння професійними уміннями.

Метою професійно-прикладної фізичної підготовки $\epsilon$ підвищення рівня професійно важливої фізичної і психологічної підготовленості, яка б дозволила будувати процес фізичного виховання майбутніх учителів відповідно до дидактичних правил навчання та уміння їх передати наступним поколінням, досягаючи тим самим сформовану світоглядну фізичну, професійну й моральну підготовку.

Вивчення проблеми професійно-прикладної підготовки у процесі фізичного виховання доводить, що слід покращити просвітницьку роботу, пропагувати здоровий спосіб життя, надавати більше інформації про вимоги до майбутньої професії та підготовку до неї, урізноманітнювати форми і методи роботи, використовувати новітні технології тощо [5, с. 116].

У навчальній програмі 3 фізичного виховання наголошується, що одним iз головних критеріїв ефективності фізичного виховання $\epsilon$ знання основ ППФП й уміння застосовувати їх на практиці [7]. Теоретична готовність майбутніх учителів 3 професійно-прикладної фізичної підготовки характеризується володінням комплексу теоретичних відомостей та певним обсягом знань, що необхідні для виконання ефективної педагогічної діяльності. Разом 3 тим, майбутній педагог повинен досконало знати i використовувати у своїй професійній діяльності відповідні поняття, категорії і формулювання з ППФП. Тобто майбутній учитель повинен володіти відповідним обсягом знань з основ ППФП, що є важливим для компетентності вчителя, його пізнавальної і практичної діяльності. Для виконання професійних обов'язків на достатньо високому рівні майбутній учитель зобов' язаний знати:

- основи ППФП й уміти застосовувати їх на практиці;

- основи дотримання ЗСЖ; 
Під час визначення психолого-педагогічних чинників, що впливають на процес формування професійної спрямованості, необхідним $є$ врахування етапів формування ППФП особистості: періоди професійної передорієнтації; професійної орієнтації з фазами орієнтації, вибору спеціальності та вищого закладу освіти абітурієнтом; навчання професії з фазами навчально-професійної адаптації, базової навчально-професійної підготовки, спеціалізації, набуття професійної кваліфікації відповідного освітньо-кваліфікаційного рівня; кваліфікованої професійної праці 3 фазами соціально-професійної адаптації, підвищення соціально-професійної кваліфікації, соціально-професійного вдосконалення.

Складність формування ППФП студентів полягає в тому, щоб віднайти підхід до кожного студента, створити умови для фізичного вдосконалення з виду спорту, тобто розвивати фізичні якості, закладені в кожному; спонукати до спортивномасових чи фізкультурно-оздоровчих заходів, організація яких неможлива без сформованих умінь і навичок, які збагачують професійну діяльність, формують суспільні цінності, збагачують спортивний дух та єдність колективних дій.

Опитування майбутніх учителів надає підстави стверджувати, що 46,5\% студентів займаються фізичною культурою і спортом постійно, регулярно і 53,5\% студентів рідко або практично не займаються. Цей показник свідчить, що необхідно збільшити академічні години на фізичну культуру і спорт для успішності в подальшій професійній діяльності. Оволодіння студентами уміннями і навичками проведення спортивно-масових заходів у групі, на курсі, потоці, факультеті дозволяє розглядати це як спеціально створену ситуацію професійної самоорганізації.

Необхідною умовою повноцінного й ефективного виховання професійноважливих здібностей майбутнього фахівця $€$ загальна фізична підготовка, що передбачає визначений розвиток сили, швидкості, витривалості, гнучкості та спритності, а також бездоганне функціонування життєво важливих систем, що вказувало б на придатність студента до фізичних навантажень різного обсягу та інтенсивності [1, с. 220].

Фізичне виховання формує систему ціннісних орієнтацій особистості на професійну майстерність, забезпечує мотиваційну, інформаційну, функціональну та рухову готовність студента до майбутньої професійної діяльності. Вона здійснюється відповідно до загальних та специфічних для ППФП закономірностей, принципів та правил педагогічного процесу, впливає на інтелектуальні, психічні, морально-вольові та інші якості особистості. Фізичне виховання визначає закономірності підтримання та вдосконалення фізичного розвитку та підвищення рівня фізичної підготовленості студента як невід'ємних характеристик здоров'я.

Одним із найважливіших завдань ППФП - формування у здорових студентів уявлення про нерозривну єдність успішної майбутньої діяльності і систематичних занять фізичними вправами вирішує педагогічна практика. Головним чинником педагогічної практики передусім $€$ рівень професійно-педагогічної підготовки студентів, їх ступінь оволодіння рухливими уміннями і навичками з видів спорту, що передбачені змістом шкільної програми 3 фізичної культури. Оволодіння технічною підготовкою 3 видів спорту, дозволить їм чіткий i доступний показ фізичних вправ, що підвищить якісне засвоєння фізичних вправ школярами. У науковій літературі зазначається що сучасний учитель фізичної культури має бути добре розвинутим фізично та мати міцне здоров'я або ж мати переконливо здоровий вигляд; особисто кваліфіковано демонструвати елементи рухових дій, уміло 
використовувати орієнтований та диференційований підходи до учнів, володіти знаннями та навичками з різних видів спорту [3, с. 55].

Складність реалізації окресленого напряму полягає в тому, що студент бере участь у всіх сферах діяльності (громадській, спортивній, професійній тощо). Проте, головне, щоб у нього вироблявся інтерес до професійної діяльності в галузі фізичної культури і спорту та потреба в самоорганізації й досконалості педагогічної діяльності.

Зазначимо, що педагогічна практика у структурі професіональної підготовки вчителів початкової школи 3 фізичної культури $є$ незаперечною. Організовуючи педагогічну практику в умовах сучасної початкової школи, студент повинен знати основні закономірності анатомо-фізіологічного та психічного розвитку учнів, уміло застосовувати знання, уміння i навички в навчально-виховній, фізкультурнооздоровчій та спортивно-масовій роботі та володіти уміннями науково-дослідної роботи (спостереження, аналіз та узагальнення педагогічного досвіду).

Професійно-прикладна фізична підготовка - це педагогічно спрямований процес забезпечення спеціалізованої фізичної підготовленості до обраної професійної діяльності, тобто це процес навчання, що збагачує індивідуальні професійно корисні рухові уміння і навички, виховання фізичних здібностей, від яких залежить професійна дієздатність.

Задля визначення критеріїв ППФП майбутнього вчителя фізичної культури ми враховували загальні вимоги до їх формування, тобто розвитку суб'єкта, його здатності розвивати свої здібності, саморозуміння, розкриття потенціалу варіативності фізичного виховання. Буде цілком логічно вважати ППФП системоутворювальною, що інтегрує показники професійно значущих якостей педагога, необхідних учителю фізичної культури.

Перспективою подальших досліджень у цьому напрямку $є$ розроблення окремої програми спецкурсу «Основи ППФП студентів» для психолого-педагогічного факультету спеціальності початкова освіта, оскільки отримані знання, уміння i навички 3 фізичного виховання є необхідними в майбутній професійній діяльності.

\section{Література}

1. Волков Н. Формування структури професійних здібностей студентів у процесі фізичної підготовки / Н. Волков // Фізична культура, спорт та здоров'я нації: зб. наук. праць. - Випуск 5. - Вінниця: ДОВ «Вінниця», 2004. - С. 220-224. 2. Божик М. В. Теоретична підготовленість вчителів-предметників 3 професійноприкладної фізичної підготовки як ефективна умова формування готовності до професійної діяльності/ M. В. Божик// Науковий часопис Національного педагогічного університету імені М. П. Драгоманова. Серія № 15. «Науковопедагогічні проблеми фізичної культури / Фізична культура і спорт». - К. : Вид-во НПУ ім. М. П. Драгоманова, 2013. - Том. 1 - Вип. 7 (33). -С. 45-51. 3. Бойко О. О. Сучасні вимоги до професійної підготовки учителів фізичної культури / О. О. Бойко // Науковий часопис Національного педагогічного університету імені М. П. Драгоманова. Серія № 15. «Науково-педагогічні проблеми фізичної культури / Фізична культура і спорт». - К: Вид-во НПУ ім. М. П. Драгоманова, 2013. - Том.1. - Вип. 7 (33). - С. 52-57. 4. Зеленська Н. Теоретична професійнопедагогічна підготовка вчителя в автономних вищих навчальних закладах України другої половини XIX початку XX століття: ретроспектива, актуалізація / Н. Зеленська // Науковий часопис Національного педагогічного університету імені М. П. Драгоманова: зб. наук. праць. - К. : Вид-во НПУ ім. М. П. Драгоманова, 2008. - С. 35-42. 5. Ломака Ж. М. Професійно-прикладна фізична підготовка в 
професійному аграрному ліцеї / Ж. М. Ломака, I. Люшненко // Матеріали V Всеукр. наук.-практ. конф. [Проблеми сучасної валеології, фізичної культури та реабілітації] (Херсон, 7 квітня 2011 р.) / М-во освіти і науки України, Херсонський державний університет. - Херсон : ХДУ, 2011. - С. 114-116. 6. Петров А. Формування суб'єктивної професійної позиції майбутнього вчителя фізичної культури в освітньому процесі ВНЗ / Андрій Петров // Фізична культура, спорт та здоров'я нації: зб. наук. праць Вінницького державного педагогічного університету імені Михайла Коцюбинського. - Вінниця: ТОВ «Ландо ЛТД», 2013. - С. 170-175. 7. Фізичне виховання. Навчальна програма для вищих навчальних закладів України I-III, IV рівнів акредитації. - Київ, 2003.

Тетяна Армаш

\section{РОЗВИТОК КОМПЕТЕНТНОСТЕЙ МАЙБУТНІХ УЧИТЕЛІВ ІНФОРМАТИКИ У ПРОЦЕСІ НАВЧАННЯ ЛІНІЙНОЇ АЛГЕБРИ}

Армаш Т. С. Розвиток компетентностей майбутніх учителів інформатики у процесі навчання лінійної алгебри.

Розглянуто основні компетентності майбутнього вчителя інформатики та виокремлено ті із них, які формуються під час вивчення лінійної алгебри, у статті виокремлено виробничі функції й уміння студента-інформатика, що формуються під час вивчення лінійної алгебри.

Ключові слова: учитель інформатики, лінійна алгебра, професійна підготовка, компетентність.

Армаш Т. С. Развитие компетентностей будущих учителей информатики в процессе обучения линейной алгебры.

Рассмотрены основные компетентности будущего учителя информатики и выделены те из них, которые формируются при изучении линейной алгебры, в статье выделены производственные функции и умения студента-информатика, формируемые при изучении линейной алгебры.

Ключевые слова: учитель информатики, линейная алгебра, профессиональная підготовка, компетентность.

Armash T. S. The development competencies of future informatics teachers in the learning process linear algebra.

Considers the main competence of future teachers of informatics and allocated those that are formed in the study of linear algebra, the article allocated production functions and abilities of the student-computer science generated in the study of linear algebra.

Key words: Teachers of computer science, linear algebra, professional training, competence.

Згідно 3 галузевими стандартами вищої освіти України освітньокваліфікаційна характеристика (OKX) й освітньо-професійна програма (ОПП) підготовки бакалавра 3 інформатики передбачає його готовність працювати й набувати навичок знань 3 інформаційних технологій, математичного i комп'ютерного моделювання процесів і систем різної природи, задач прогнозування, оптимізації, системного аналізу і прийняття рішень тощо [1;2]. Бакалавр повинен мати основи математичних знань і застосовувати їх на практиці, 